This is a self-archived version of an original article. This version may differ from the original in pagination and typographic details.

Author(s): Uskali, Turo; Gynnild, Astrid

Title: Drones, teaching and the value of the explorative player-coach

Year: 2018

Version: Published version

Copyright: (c) Authors, 2018

Rights: $C C B Y-N C-N D 4.0$

Rights url: https://creativecommons.org/licenses/by-nc-nd/4.0/

Please cite the original version:

Uskali, T., \& Gynnild, A. (2018). Drones, teaching and the value of the explorative player-coach. In A. Gynnild, \& T. Uskali (Eds.), Responsible Drone Journalism (pp. 58-70). Routledge. https://doi.org/10.4324/9781315163659-5 


\title{
5 Drones, teaching and the value of the explorative player-coach
}

\author{
Turo Uskali and Astrid Gynnild
}

\section{Introduction}

While the market for civilian drones - in all shapes and forms - has exploded in recent years, there are amazingly few courses offered on how to fly drones. More precisely, even if camera drones are now widely used by journalists on all continents, journalism programs seem to be lagging behind when it comes to integrating this disruptive tool into their teaching. By contrast, anecdotal evidence suggests that in disciplines such as geography, architecture, landscaping, agriculture and engineering an increasing amount of resources is invested into preparing students for the emerging drone future. Thus, we wanted to find out why and how a few journalism schools have truly flown out of the mainstream. We start with Finland and from there broaden the scope to early adopters in the United States and elsewhere.

The diffusion of civilian drones is particularly interesting to follow in a time when journalism education is under great pressure. As educators of students to an unknown future, we are obliged to adapt quickly to the new technological, economic and social-cultural changes that challenge the work roles and practices of journalists and other media workers. Simultaneously, teachers of journalism typically want to maintain all the core skills and virtues of the profession: being critical, writing excellently, using multiple sources and holding people in power accountable (Goodman \& Steyn 2017; Hovden, Nygren, \& Zilliacus-Tikkanen 2016; Terzis 2010).

Depending on assessment perspective, journalism educators are typically expected to fulfill different roles in their teaching: they might be judged as university professors concerned with critical thinking and media theory; they might be judged by their ability to focus on hands-on training of core journalism skills and values; they might be considered newsroom managers who should train operational competitiveness and speed. Or they are expected to be technological optimists who, in line with many editors and 
CEOs, are convinced that new technologies are the utmost solution to most journalism challenges. Yet another option is to judge whether journalism teachers follow their entrepreneurial instincts and skills.

Mark Deuze (2006) summed up by suggesting that journalism education might choose between two major positions in society: the "follower" mode or the "innovator" mode. Based on the aforementioned literature, it appears that most journalism schools have traditionally chosen the follower role, emphasizing the core skills and sustaining old, conservative course modules; in other words, they play it safe.

Taking a role as a proactive facilitator of emerging trends and gadgets does not necessarily imply riskier risk taking, so to speak. It often tends to be overlooked that much risk taking associated with entrepreneurial approaches in real life do not apply directly to journalism education. An interesting difference is, for instance, that while entrepreneurs have to constantly keep looking for new ways of creating rapid and sustainable revenue, journalism teachers can experiment without risking loss of their jobs or loss of their colleagues or employees. The only thing teachers might risk is actually losing students if the journalism courses they teach do not appear up-to-date. Rather, this study indicates, in a time of constant change and tough production pressure, journalism programs at universities might be very well suited to creative experimentation and the nurturing of innovative mind-sets among students.

Journalism education has, just like other professionally oriented programs, been criticized for making students good at reproducing material but less trained in learning by doing. The Department of Communication at the University of Jyväskylä in Finland, however, has deliberately taken another stance and established a different kind of reputation. The journalism school in Jyväskylä was among the first in the world to introduce innovation to the curriculum: the first courses in innovation journalism were held in 2004 (Lassila-Merisalo \& Uskali 2011). The allocation of resources to journalism innovation might partly be explained by teacher visits to Silicon Valley and Stanford University. Additionally, the department had a competitive advantage in being small and could easily and without risk change its bachelor and master programs in the desired direction.

With drones, the staff and students at Jyväskylä are again among the first in line. Students at this university were trained in using camera drones long before the drone issue was brought up in Finnish newsrooms. More than 30 graduate students, experienced in piloting drones, entered Finnish newsrooms after the first drone course was held in 2014. It is still a bit early to conclude in what ways their dronalism skills will affect Finnish media and society. But if we reason deductively, there should be a fair chance that the expertise in drone piloting will be considered an asset to the newsrooms. 
The open-minded course design suggests that teachers and students engage in a peer-to-peer learning environment in which the speed of learning accelerates through rigorous experimentation.

\section{Research question and challenges}

Two burning questions to be investigated in this chapter are thus why drone courses are run in Jyväskylä and how they are facilitated. What was the philosophy behind this particular active learning approach, except that the university's Department of Communication clearly considers innovation journalism to be a part of its mission? The further discussion in this chapter is based on empirical data from the courses, such as curriculum, continuous dialoguing with students, student evaluations and reflexive discussions and notes carried out by the teachers.

A main challenge with the learning-by-doing approach of a new technology such as civilian drones is obviously the lack of knowledge and lack of access to relevant manuals on how to operate drones. Add to this challenge that by the time the first drone journalism course was held at the University of Jyväskylä there were no special rules for using unmanned aerial vehicles in Finland. Teachers and students operated indoors and outdoors and were free to experiment within amazingly wide frames. Even after the introduction of national regulations in October 2015 (Trafi 2015), the Finnish drone rules are still quite liberal compared to those of many other countries (Lauk et al. 2016).

Within such wide frames, what was then the best way to introduce new tools like camera drones to master students? That was the main question posed by the journalism teachers before the course started. After three years of experiential learning, the teachers are still asking the same question. Thus, a main aim of this chapter is to recapture, refocus and reflect on the intensive learning processes that actually took place during these courses. Admittedly, to begin with, the teachers did not take on any structured pedagogical approach except that, with an open mind, they started pondering the aforementioned questions. Following the theorizing of Peter Drucker on the entrepreneurial society (2014), it appears that the teachers, as well as the students, engaged enthusiastically in an intuitive learning-by-doing approach.

\section{Experiential learning as a theoretical framework}

In order to understand the learning processes that were constantly going on in parallel with an intensified focus on practicalities, we lean on the theory of experiential learning developed by Kolb (1984) and the theorizing of learning space (Kolb \& Kolb 2005). As previously discussed by Gynnild 
(2016), the experiential learning approach has widely influenced university teaching across disciplines but is in particular applicable to theory-practice approaches of Nordic journalism programs. It should be noted here that the term experiential is not a writing error but a concept developed from experimentation, on the one hand, and experience on the other.

Following Kolb's experiential learning theory, then, learning is cyclical in the sense that it follows a pattern that repeats itself. First, students learn from directly experiencing the events. Second, students learn from reflecting on these experiences. Third, students learn from conceptualizing these experiences, and fourth, students test what they have learned by applying the new knowledge. At every step of the cycle, new learning ideally leads to constantly progressing reflections and discussions that feed the further perception and understanding of what is going on.

\section{Learning by experiencing}

In the following paragraphs, we provide some descriptive examples of concrete challenges that had to be resolved by teachers as well as by students in Jyväskylä when experimenting with drones. What lessons were learned, and how were these issues handled by the educators? The challenges concern, in the first instance, practical issues such as types of drones, weather limitations, flying space and flying practice needed. They add to the understanding of what is needed for journalism experimentation to take place. Next, we compare these experiences with parallel processes going on in higher education in the United States. By analyzing these data in turn, we arrive at three aspects that journalism teachers have in their roles as leaders of active learning processes of future journalists.

With hindsight, the initial use of drones in the Jyväskylä journalism program did bring with it a good deal of risk taking. The course started out with Parrot AR, a French drone that in 2010 had become the first civilian bestseller (Goldberg, Corcoran, \& Picard 2013). A main difficulty with this lightweight drone model was that even mild winds easily caused disruptions. One of the first student flights ended on the rooftop of a block of flats in the city center of Jyväskylä. After several minor crashes by other students, the drone was wrecked, and teachers started looking for more advanced drone models. The first model of Parrot AR was still a toy, not a proper tool for journalism, as experienced by other drone educators as well.

In 2015, the master program bought its first DJI Phantom 2, which was assessed in this way by The Economist (2015): "That brought professionalquality aerial photography within the reach of general users." Later the same year the teachers invested in two Chinese Yuneec's Typhoon Q500s, followed by another new model DJI Phantom 3 4K. In 2017 two DJI Mavic 
Pros were added to the fleet. A lesson learned is that to improve drone journalism education, one has to be willing to invest constantly in new drone models. A broad rule of thumb is that one drone will be lost per course.

Another issue that had to be resolved on the spot was the question of time needed for flying. For example, in order to be a helicopter pilot, a minimum 40 hours is required in many countries, but actually most candidates practice more (Perritt \& Sprague 2017). Some experts have argued that formal training requirements for using drones may not be necessary at all. Perritt and Sprague (2017) emphasized that one has never needed a license to fly model airplanes or to use chainsaws or lawn movers. More importantly, according to Federal Aviation Administration rules (FAA 2016), and upcoming European Union rules on unmanned aerial vehicles, at least a theoretical online test is needed for piloting drones for journalistic purposes.

The minimum requirements for the University of Jyväskylä students, before starting operating the drones themselves, were to participate in at least 80 percent of the classes (10 hours of theoretical lecturing), and have at least 60 minutes of practical flying time under the supervision of the instructors. All flying practice sessions were held at the university's sports field.

After the first direct experiences, and much discussion and reflection among the teachers, it became evident that drone flight practice did require clear prescriptions on every step of the process. This learning lesson is supported by the findings of Perritt and Sprague (2017). Clear structures are needed for a) preflight preparation and procedures, b) takeoffs and landings, c) hovering maneuvers (in slow/fast modes), c) short-term missions, d) aerial image and video practices, e) emergency operations (including using the autopilot) and f) post-flight procedures, which include, for instance, documentation in the flight log and recharging the batteries.

The next learning lesson concerns weather conditions, which matter greatly in drone piloting. In general, the best time for outdoor practicing, especially in the Nordic countries, is from the late spring to summer and early autumn. In the case of days that are too windy or rainy, the practice sessions were sometimes moved indoors, to a TV studio, and the outdoor drones were switched to mini-drones. Failing safely became important when using the toy-like mini-drones. These drones were particularly difficult to operate; a one-minute flight was record-breaking. Also using the drone piloting simulators offered by the manufacturers was helpful when outdoor practice was not possible.

After four weeks of lectures and practice, students were able to test what they had learned. The main homework was to produce a drone journalism story, in pairs, without any help from the instructors. The themes for the short video stories varied from the city dump and a Pets' Day cavalcade to students' festivities and sport events. All 25 students went through the lectures 
and practical training sessions, but four students did not return the drone course work (a short drone video and a course feedback report) in order to pass the course and get a grade. In general, it is typical in advanced, MAlevel voluntary journalism courses that some students will drop out during the course because of coursework overload from other courses.

As the educators engaged actively in the learning-by-doing-approach themselves, a next step was to collect written feedback systematically from the students. The educators were hungry to get constructive critiques in order to develop the course further. All the students who answered the survey $(\mathrm{N}=21)$ were overwhelmingly positive and considered the drone journalism course very successful. One student commented that the course served as an "eye-opener." Another student said, "The best course ever: educative and fun." One student even postponed her graduation because she wanted to take the course. All the students also wanted to recommend the course to other students and advised instructors to continue the course, despite some setbacks.

On the more critical side, most students wanted to have more time for piloting the drones. Sixty minutes was not perceived as sufficient to ensure basic skills for operating the drones safely. The students also suggested more challenging practicing places than the open campus sports field; some students even suggested a special test arena for drone practicing. Finally, according to the survey, too many drone videos were watched during the lectures.

Indeed, calculating the numbers of broken or completely wrecked drones, the dropout rate, and the students' feedback, one can argue that at a practical level, the basic course model still needed some improvement. Another rather obvious rule of thumb is that the more practice one gets, the better one becomes at drone piloting; one hour of flight time was obviously not enough for preventing crashes. Therefore, in 2017 the new minimum drone piloting time was extended to 60 minutes in the sports field and 60 minutes in more challenging environments - all in all, two hours. Moreover, in the current drone courses at the University of Jyväskylä, the students have to pass two tests in order to get a "license" to operate the drones by themselves: one online test and one practical flying test. Passing the drone journalism course will give the students the permit to use the drones for other journalism courses as well. In this way, the educators hope camera drones will be just a new tool to students' tool pack for visual storytelling.

The frames for drone experimentation at the University of Jyväskylä have changed to reflect new Finnish drone rules. The regulations require that the department inform the Finnish aviation authorities about all drone operations. A drone operator's manual was written, and educators have to log all drone flights. Special drone insurance is purchased. Every time teachers and 
students want to use the drones, they need to ask the City Airport for permits by phone. The City Airport also wants to be informed when operations are finished. A special app published by the Finnish aviation authorities in 2017 includes updated information about the no-fly zones and other restrictions. The app uses the location of the user and displays the current situation in colors: red means no-fly-zone or call the nearest airport to check whether it is possible to operate the drone in the area. Green allows all kinds of drone activities.

Altogether, the new governance of unmanned aerial vehicles in Finland means that drone journalism education constantly adapts to new outer frames for experimentation. In a sense, one might conclude that stricter regulations point in direction of a more responsible model of drone journalism in higher education. But do these regulations, together with continuous reflections on one's own experiences, necessarily ensure that drone journalism education becomes responsible? Before we continue this discussion, we want to discuss the pioneering drone activities in American journalism.

\section{Lessons learned in the United States}

The educative lessons learned in the US are based on experiential learning as well. Whereas educators in Finland engaged in developing a Finnish model for dronalism, the Drone Journalism Lab at the University of Nebraska-Lincoln (Los Angeles Times 2011) has become a leading institution for facilitating drone journalism in the US. Its founder, Professor Matt Waite, was among the first to realize the importance of camera drones for journalism. Another early mover was Chris Anderson, Wired Magazine's editor-in-chief. He started to customize drones with his children in 2007 and later moved from journalism to become a drone entrepreneur and do-ityourself community facilitator (Anderson 2012).

As previously innovative journalists and devoted drone enthusiasts, Waite and Anderson exemplify what Peter Drucker would call leaders as explorers. In journalism, they also represent the decreasing but very important group of creative news professionals, constantly hunting for news in the sense of being first with the latest - in new fields. The Drone Journalism $\mathrm{Lab}$, for instance, obviously took an exploratory stance from the beginning. A main aim of the Lab was to search for answers to new questions by doing and experimenting. For example, Waite's first flying attempts with the Parrot AR ended in many indoor and outdoor crashes. The experiments were thoroughly documented in Waite's detailed reports on the incidents:

At about 5:30 p.m. CST Dec. 28, 2011 during a test flight to gauge the effectiveness of a new camera mount, the drone operator lost control 
of the aircraft while it was flying over his house. The drone was flying away from the operator and not responding to commands to turn away from the house. The operator panicked and the emergency shutdown signal was triggered causing the drone to crash onto the roof, slide off the back of the house and fall two stories to the ground below.

(Waite 2011b)

After his analysis of the main reasons for the crash, Waite reflected and instructed that one should not fly at night, avoid panicking and find control systems other than smartphone and Wi-Fi. Later, Waite added to the list that one should have a budget for the replacement parts. The crash damaged the front-facing camera and the landing bed. After the first weeks of testing, Waite concluded, "Crashing is a part of this, especially starting out" (Waite 2011a).

In 2013, the second drone journalism program in the US was started at the Missouri School of Journalism in collaboration with the University of Missouri Information Technology program. The project's goal was to discover how best to utilize drone technology in the field of journalism.

A striking feature of the American education initiatives is the intensive production of blog posts. Similar to that of the Drone Journalism Lab, the website www.missouridronejournalism.com has become one of the main news curators on drone journalism. Blogs typically serve as valuable outlets for reflection in action and collective sharing of experiences. The Missouri school's first drone journalism story was a clip about the unusual amounts of snow geese in the area. From the beginning, the blog posts of the Missouri project attracted international reporters from countries such as South Korea to observe the program on the spot (Garcia 2013).

Contrary to the first Nordic experiments with drones in journalism, which were hardly mentioned in blogs, the transparency of the American drone educators soon got them into trouble. The blog reports led to much attention from other bloggers and from the news media. Rumors and false information were circulated especially via conservative blogs - for example, that the Environmental Protection Agency (EPA) was using drones to spy on feedlots in Nebraska. According to Pham (2013a), the conservative lawmakers teamed up with the American Civil Liberties Union in legislatures all over the country. As a result, by the summer of 2013, six states successfully passed anti-drone laws, and 28 states (including Missouri) had antidrone laws active in statehouses. The two research and education programs on drone journalism in the United States, Nebraska and Missouri, were subsequently halted by the authorities because they lacked special permits (Pham 2013a, b; Waite 2013). Drone journalism education in the US was halted from 2013 to 2016. In this period it was unclear on what premises, if any, teachers and students were allowed to operate drones. 
After more than two years in "stealth mode," in October 2015, The Missouri drone journalism program again started to post its operations publicly on its blog. During the silent time, the program adjusted their physical learning spaces; they felt forced to continue flying practice indoors in a livestock arena. Moreover, the educators and researchers found a new creative outlet by going on reporting trips abroad, for instance, two weeks of field reporting in Costa Rica, and later in Zambia. (Missouri Drone Journalism 2015; Shaw 2015a, 2015b).

"Schools and universities are incubators for tomorrow's great ideas, and we think this is going to be a significant shot in the arm for innovation," said an FAA administrator in a BuzzFeed news story in May 2016. According to the FAA, the students were then allowed to use the drones for their schoolwork in high schools and colleges. The federal regulators defined drone schoolwork as a hobby or recreation, not as a commercial activity. Because teachers are paid, their use of drones is treated differently. In the story, Matt Waite argued that "the prohibition on teachers flying drones puts serious limits on the new policy's efficacy" (Shaban 2016).

Similar to many other countries, drone programs are spreading across universities and colleges in the United States. In late 2017, at least 16 different programs are up and running, but only two focusing on drone journalism (Dronethusiast.com 2017). The courses in higher education are typically supplemented by workshops, boot camps, hackathons and other activities outside of the universities. For instance, in China, People's Daily Website, Xinhua News Agencies and the China Daily website have joined forces with local drone makers to improve digital news coverage (Zheng 2016). In addition to face-to-face and hands-on educational modules, many online tutorials and simulator programs for a variety of drone models are offered by the drone manufacturers for self-learning (Perritt \& Sprague 2017).

\section{Discussion}

From the many blog posts, videos and online discussions behind this study, there are, however, many voids when it comes to student experiences with drone journalism. The voices that dominate online educative forums are those of teachers - meaning teacher-managers, teacher-entrepreneurs or teacherleaders, depending on the role that fits best. These front-runners apparently display very valuable qualities as leaders and spokesmen of journalism innovations, such as adopting drones as a newsgathering tool. Teachers in higher education are, contrary to managers and CEOs in mainstream newsrooms, not concerned about operational efficiency and competitiveness. Rather, they appear to be immersed in a kind of creative competitiveness in which the reward is not money but being first with the latest innovation. 
As Drucker pointed out, building creatively competitive organizations requires curiosity first and foremost; asking questions is valued higher than providing answers.

Along such parameters, we argue that journalism programs in higher education have many assets, such as labs for journalism innovation. One of the most important assets is journalism teachers who passionately engage in innovation processes and intuitively lead students toward creative competitiveness. Following Drucker, leaders or teachers of creatively competitive organizations, exemplified also by some journalism schools, take on three different roles in the cycles of innovation (Brown 2016): The first role is that of the explorer, the person who is in front. The explorer leads by asking strategically purposeful questions that typically might bring great value to the institution. The second role is that of the gardener, which is more of a leading-from-behind; the gardener foresees and provides tools and spaces for purposeful experimentation and innovation. The third role is that of the player-coach, which implies to lead from the side without taking over what the students are doing. The player-coach is supposed to anticipate what problems may arise and follow and support the students as they actively engage in resolving the issues with which they are working. The liberty of journalism teachers lies in not having to worry about the revenue on a daily basis, unlike entrepreneurs in the industry.

From the data in this study, the outstanding position as journalism innovation schools in Finland as well as in the American states of Nebraska and Missouri did not evolve by accident. The institutions took on these roles because they nurtured teaching leadership directed toward creative competitiveness instead of operational efficiency. The opening up for journalism innovation first attracted more devoted teachers. In the next round, the facilitation of innovation opportunities represented by drones most likely attracts students who see drone expertise as a competitive advantage. According to Kolb and Kolb's theorizing on learning spaces (2005), it is crucial that members of a learning community are known and respected by faculty and by colleagues. They need to feel that they are allotted a space.

And yet we argue that when it comes to facilitate critical and questioning approaches to drones in a societal perspective, journalism schools still have much to learn. That is the case at least if we place the drone journalism courses in a responsible research and innovation (RRI) perspective. At this point in drone journalism history, it appears that educators are still mostly concerned with the practicalities of piloting drones as a newsgathering tool. There is little discussion about drones as a news beat, even though millions of Euros and dollars are invested in the skyrocketing civilian drone industry. Moreover, even though several thousand civilians in the Middle East have been killed by drone warfare, these actions go on with little interference from the news media. So 
the following questions arise: In what ways might students best be provoked to begin debating the many unresolved issues of military and civilian uses of drones? In what ways might responsible droning be taught in ways that take into consideration the potential bad uses of the new technology?

Based on the study of early drone adopters in education, we do not have a single good answer to these questions. But we would like to throw in a last idea from the side: now that the first phase of drone teaching in journalism is settled, would there be more space for critical thinking and critical dialogue on the opportunities and dilemmas of drones? This would require consideration of drones not just as a newsgathering tool for journalism explorers but as an increasingly important military and civilian industry that deserves to be covered more broadly as a news beat.

Whereas critical thinking is considered a basic communication skill to be learned in bachelor programs, Morris (2017) suggests that teachers in higher education should focus more on critical dialogue. She claims that critical dialogue is "an active group process and opportunity for students and faculty members to learn how to engage in civil, respectful, difficult conversations." She points out that when engaging in critical dialoguing, teachers and students will "tap not only into the cognitive domain, but also into our attitudinal and behavioral predilections. Critical dialogue is learned in community and serves the community, and the process can unite students and faculty members from divergent backgrounds and viewpoints around difficult, yet shared, issues and problems" (Morris 2017, p. 1).

As suggested in a previous study of journalism innovation (Gynnild 2016), in order for innovation journalism to expand as a news beat, journalists need to explore what innovation entails in practice. With the experiential learning about drones conducted in higher education, the journalists of tomorrow are getting a flying start technically. The question is this: In what ways might the competencies already achieved extend to integrate the difficult issues as well? Ideally, critical dialogue should be a perfect match for journalism students who are trained in posing direct and provocative questions of all types. The only dilemma - and one that is apparently increasing - is that journalism educators and their students might be immersed in their own drone experiments to the extent that critical thinking and critical dialoging on behalf of society are lost. Therein lies a challenge for journalism teachers as explorers, gardeners and player-coaches.

\section{References}

Anderson, C. (2012) How I Accidentally Kickstarted the Domestic Drone Boom. Wired, [online], 22 June 2012. Available from: www.wired.com/2012/06/ff_drones/ [Accessed 10 March 2017]. 
Brown, T. (2016) Leaders Can Turn Creativity into a Competitive Advantage. Harvard Business Review, 2 November.

Deuze, M. (2006) Global Journalism Education: A Conceptual Approach. Journalism Studies, 7 (1), pp. 19-34.

Dronethusiast.com (2017) 16 Top Drone Programs at Universities and Colleges, [online]. Available from: www.dronethusiast.com/top-universities-unmanned-aerialsystem-programs/\#Accredited [Accessed 11 April 2017].

Drucker, P. (2014). Innovation and entrepreneurship. London: Routledge.

FAA (2016) Operation and Certification of Small Unmanned Aircraft Systems, [pdf]. Available from: www.faa.gov/uas/media/RIN_2120-AJ60_Clean_Signed. pdf [Accessed 2 April 2017].

Garcia, Z. (2013) Korean Journalists Observe a Class, Drones in Flight. Missouri Drone Journalism, [online]. Available from: www.missouridronejournalism.com/2013/04/ korean-journalists-observe-a-class-drones-in-flight/ [Accessed 10 April 2017].

Goldberg, D., Corcoran, M. and Picard, R. G., eds. (2013) Remotely Piloted Aircraft Systems and Journalism: Opportunities and Challenges of Drones in News Gathering. Oxford: Reuters Institute for the Study of Journalism.

Goodman, R. S. and Steyn, E., eds. (2017) Global Journalism Education: In the 21st Century: Challenges \& Innovations. Austin, TX: Knight Center for Journalism in the Americas.

Gynnild, A. (2016) Developing Journalism Skills Through Informal Feedback Training. In Hovden, J. F., Nygren, G. and Zilliacus-Tikkanen, H. eds. Becoming a Journalist: Journalism Education in the Nordic Countries. pp. 321-332. Gothenburg: Nordicom.

Hennigan, W. J. (2011) Idea of Civilians Using Drone Aircraft May Soon Fly with FAA. Los Angeles Times, [online]. Available from: http://articles.latimes.com/2011/ nov/27/business/la-fi-drones-for-profit-20111127 [Accessed 10 March 2017].

Hovden, J. F., Nygren, G. and Zilliacus-Tikkanen, H., eds. (2016) Becoming a Journalist: Journalism Education in the Nordic Countries. Gothenburg: Nordicom.

Kolb, A. Y. and Kolb, D. A. (2005) Learning Styles and Learning Spaces: Enhancing Experiential Learning in Higher Education. Academy of Management Learning \& Education, 4 (2), pp. 193-212.

Kolb, D. A. (1984) Experiential Learning. Englewood Cliffs, NJ: Prentice-Hall.

Lassila-Merisalo, M. and Uskali, T. (2011) How to Educate Innovation Journalists? Experiences of Innovation Journalism Education in Finland 2004-2010. Journalism \& Mass Communication Educator, 66 (1), pp. 25-38.

Lauk, E., Uskali, T., Kuutti, H. and Snellman, P. (2016) Droonijournalismi: Kaukoohjattavien kamerakoptereiden toimituskäyttö. ["Drone Journalism: Utilizing Remotely Piloted Aircrafts (RPA) in Journalistic Purposes”']. Jyväskylä: University of Jyväskylä.

Missouri Drone Journalism (2015) Class of Drones, [Online Video], 15 September 2015. Available from: www.youtube.com/watch?v=D_8UipaLJGc [Accessed 10 April 2017].

Morris, L. V. (2017) Moving Beyond Critical Thinking to Critical Dialogue. Innovative Higher Education. doi: https://doi.org/10.1007/s10755-017-9413-z.

Perritt, H. H., Jr. and Sprague, E. O. (2017) Domesticating Drones: The Technology, Law, and Economics of Unmanned Aircraft. London: Routledge. 
Pham, S. (2013a) Missouri Drone Journalism Program to Reconfigure Goals after FAA Letter. Missouri Drone Journalism, [online], 21 August. Available from: www.missouridronejournalism.com/2013/08/missouri-drone-journalism-programto-reconfigure-goals-after-faa-letter/ [Accessed 10 April 2017].

Pham, S. (2013b) When Journalism Becomes a Game of Drones. Mashable, [online], 28 July.Available from: http://mashable.com/2013/07/28/game-of-drones-journalism/\# m2uoU7ni.sqy [Accessed 21 March 2017].

Shaban, H. (2016) Students Can Now Fly Drones at School, FAA Says. BuzzFeed, [online], 4 May. Available from: www.buzzfeed.com/hamzashaban/studentscan-now-fly-drones-at-school-faa-says?utm_term=.viVv2BeoZ\#.pwdQ8wgDv [Accessed 13 April 2017].

Shaw, R. (2015a) Costa Rica Trip. Missouri Drone Journalism, [online], 16 November. Available from: www.missouridronejournalism.com/2015/11/costarica/\#more-518 [Accessed 10 April 2017].

Shaw, R. (2015b) Drone Journalism Website Returns to Action. Missouri Drone Journalism, [online], 1 October 2015. Available from: www.missouridronejournalism. com/2015/10/drone-journalism-website-returns-to-action/[Accessed 10April.2015].

Terzis, G., ed. (2010) European Journalism Education. Bristol: Intellect, Limited.

Trafi Finnish Transport Safety Agent (2015) The New Aviation Regulation on the Use of Unmanned Aircraft and Model Aircraft, [online], 10 September. Available from: www.trafi.fi/en/about_trafi/news/3588/new_aviation_regulation_on_the use_of_unmanned_aircraft_and_model_aircraft [Accessed 10 April 2017].

Waite, M. (2011a) Crash Report No. 1. Drone Journalism Lab, [online], 30 December. Available from: www.dronejournalismlab.org/page/19 [Accessed 17 March 2017].

Waite, M. (2011b) Lesson: Budget for Replacement Parts. Drone Journalism Lab, [online], date. Available from: www.dronejournalismlab.org/page/19 [Accessed 18 March 2017].

Waite, M. (2013) Drone Journalism, the Rules and the Way Forward. Drone Journalism Lab, [online], 21 August. Available from: www.dronejournalismlab.org/ page/10 [Accessed 21 March 2017].

Zheng, L. (2016) China Daily Partners with EHang on Drone Journalism. China Daily, [online], 7 December. Available from: www.chinadaily.com.cn/business/ tech/2016-12/07/content_27602940.htm [Accessed 16 April 2017]. 